\title{
Medical aids often their own worst enemies with fraud
}

Less than a third of medical schemes in South Africa (SA) $(29.4 \%)$ use estimates of their losses to fraud, waste and abuse to decide how much they will invest in countering these practices. Most try to negotiate with offenders to mitigate their losses, making countrywide quantification almost impossible, while individual schemes fail to collaborate sufficiently, enabling crooked syndicates and individuals to move between schemes with virtual impunity. Only a minority (also $29.4 \%$ ) of schemes ensure that the people they hire to counter these practices have received professional training and accreditation for their roles.

These figures, extracted from a retrospective KPMG survey conducted 5 years ago, were cited by Jim Gee, Director of Counter Fraud Services at BDO LLP (a UK-based business and accounting firm) and Visiting Professor and Chair of the Centre for Counter Fraud Studies at the University of Portsmouth, UK. His paper, entitled 'The resilience to fraud of medical schemes in South Africa, was among three expert presentations on fraud to the annual Board of Healthcare Funders (BHF) conference in Cape Town this July. They estimate the total of annual private healthcare fraud in SA to be roughly ZAR13 billion, based on the international norm of $10 \%$ of country total spend (ZAR130 billion in SA), but readily concede that insufficient data make this little more than a thumb-suck.

Dr Hleli Nhlapo, Deputy Chairman of the BHF's Healthcare Forensic Management 
Unit (HFMU), an information- and resourcesharing group in which most medical schemes, administrators, management and administration entities and some insurers participate, said that most service providers were 'honest, healing scientists', but that there were 'outliers who mess it up for everyone', mainly by filing high volumes of false or improper low-cost claims - very hard to detect unless schemes have proper systems in place. He urged individual medical schemes to share fraud, waste and abuse data with the HFMU to enable more efficient identification of syndicates, which shape-shifted, moving from scheme after scheme when they were detected or got wind of someone on their trail. "The only time we'll get accurate percentages of fraud losses (and a higher prosecution rate) is when we all come together and work as a unit. This working in silos is a problem.' Asked how many cases the HFMU had successfully prosecuted last year, he replied 'Not a lot, there were three or four matters - which is exactly why we want better collaboration for greater success.' Nhlapo later estimated that private healthcare fraud in SA 'could be at least $7 \%$ and at most as much as $15 \%$ of the total spend, but it's all thumbsuck, the truth is we don't know. He said that the HFMU continued to work closely with the National Prosecuting Authority and the police to try to ensure more efficient prosecutions by giving them a better understanding of how the medical schemes industry worked, singling out KwaZulu-Natal as the most knowledgeable and efficient law enforcement province in this field.

\section{'50 shades of fraud ...'}

Nhlapo, a dentist whose specialty has been tracking the worst offenders (dental therapists) in his field, shared the findings of an HFMU probe into the highest-claiming dental therapists (treating pain and sepsis). Consolidating and analysing data from participating medical schemes, they found examples of dental therapists working 45 hours in a single day (v. an 8-hour day). By putting an investigator and a clinician into the field to actually question patients of suspect therapists and comparing their stories with actual claims, they found billing for services not provided to be the most common offence. 'You couldn't see what was being claimed for in the mouth,' he explained. Up-coding (doing a single filling and billing for three) and submitting dental claims under one patient's name when services were actually provided for another were also very common. There was also billing for non-covered services, falsely changing dates of service to compensate for annual benefits having run out, and abusing co-payments by (for example) taking an intraoral X-ray and charging for two, in lieu of the co-payment. Implanting of diamond and

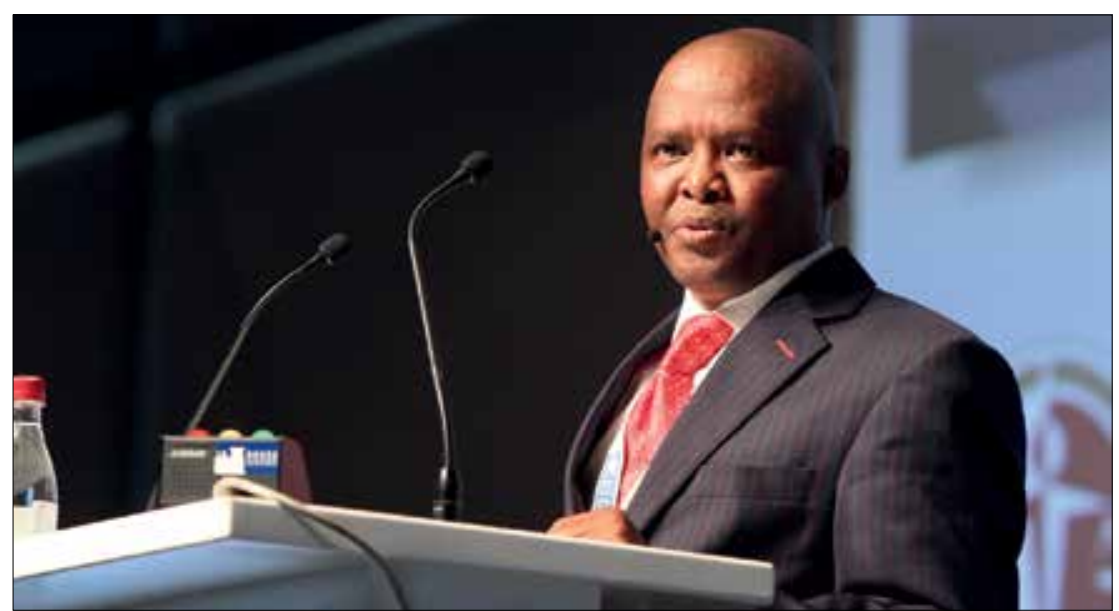

Dr Hleli Nhlapo.

gold studs under false coding was common, while dismal infection control with re-used equipment was rife. (Medical aids use codes that support the avoidance of cross-infection.) One of the most common abuses was the use of 'specials', where entire families were encouraged to come in for dental treatment and received a gold inlay for free - the proviso being that four or more family members had to be on the principal member's medical aid.

'Some of the people in the pictures we took were supposed to get 16 fillings, but all we saw was cosmetic gold inlays.' He showed mouthfuls of diseased teeth that were billed for as having been cleaned, adding that many therapists often practised well beyond their scope. Others took advantage of medical schemes holding 'wellness days' to treat patients in a corner of an office, or set up practice in substandard amenities such as Wendy houses with no lights or running water and just a hair salon chair. Nhlapos colleague Herman Havenga, Chief Operating Officer of Qubeka Forensic Services, said that one case study of collusion between pharmacists, GPs and medical aid members uncovered four main offending pharmacies (which he declined to identify), linked to another 11 pharmacies and involving 432 medical aid members. Using data analytics, they were able to show how pharmacies were being used as 'ATM machines.' 'You take a ZAR30 000 float in the morning when you open your pharmacy. The member brings his medical aid card and gets cash and groceries ... but the plot thickens when you look at GPs. What we realised is that there are false consults and prescriptions written for scheduled medication. Basically they collude to defraud the schemes.'

\section{Busted? Just change your practice number!}

When they were confronted and payments were stopped, crooked GPs and pharmacists often opened up new practices with a new practice number. 'In one particular case where a GP entered a plea agreement and agreed to appear as a state witness, we had success - but if we had worked together as an industry (the wider medical aid industry), the case wouldn't have taken us 5 years to solve,' he emphasised. Explaining the modus operandi further, he said the pharmacy customer took a basket, put in some baby food and groceries (such as soap, Dettol, skin cream). When they went to pay they were given cash to the value of a claim for (for example) inhaler medication worth ZAR1 400. 'They even put a mark-up on the goods', he added. Showing a spreadsheet to depict a crooked drug rehabilitation clinic falsely charging for the transport of patients to a pathology lab, Havenga said that the secretary who recruited medical scheme members and then turned state witness on the scam was murdered. 'This was syndicate stuff. If you don't address it collectively, we won't win. Yes, we got the Asset Forfeiture Unit in and we did get a conviction eventually here, but it would have been far quicker and better had all the medical aids worked together' One BHF conference delegate said it was his impression that schemes tended mostly to want to negotiate with providers and recover money: 'It's used as a stick - if you're willing to negotiate a settlement, then you don't get reported as a fraudulent case. I'm of the view that this distorts the actual fraud. We just don't know what the tolerance level is!' Nhlapo replied that this practice of 'settling' differed between schemes, 'but your view is true of many schemes. Some schemes are not helping us by negotiating separately.'

$\mathrm{He}$ and Havenga described a suggestion from the floor that a symposium be held to thrash out the issue as 'a brilliant idea'.

\section{Chris Bateman}

chrisb@hmpg.co.za

S Afr Med J 2015;105(11):887-888.

DOI:10.7196/SAMJ.2015.v105i11.10197 